\title{
Minyak Cengkeh (Syzygium aromaticum) Menginduksi Apoptosis pada Sel Kanker Servik HeLa melalui Peningkatan Kadar Protein p53
}

\section{Clove (Syzygium aromaticum) Oil Induces an Apoptotic Effect in HeLa Cervical Cancer Cells by Increasing p53 Protein Level}

\author{
Happy Kurnia $P^{1}$, Ihda Dian $K^{2}$, Elly Mayangsari ${ }^{3}$ \\ ${ }^{1}$ Departemen Biokimia dan Biomolekuler Fakultas Kedokteran Universitas Brawijaya Malang \\ ${ }^{2}$ Departemen Patologi Anatomi Fakultas Kedokteran Universitas Brawijaya Malang \\ ${ }^{3}$ Departemen Farmasi Fakultas Kedokteran Universitas Brawijaya Malang
}

\begin{abstract}
ABSTRAK
Kanker serviks merupakan kanker yang paling sering dijumpai pada wanita setelah kanker payudara. Kanker ini terkait dengan infeksi persisten virus yaitu Human Papillomovirus (HPV). Virus ini yang mengekspresikan protein onkogenik virus yaitu protein E6 dan E7 yang terkait dengan proses karsinogenesis. Salah satu mekanisme onkogenik virus ini adalah pengikatan protein 553 yang menginduksi degradasi oleh protein E6, mengakibatkan efek anti-apoptosis dan proliferasi sel secara terus menerus. Minyak cengkeh yang mengandung senyawa aktif eugenol telah dilaporkan memiliki efek anti kanker pada beberapa kanker. Namun, mekanisme minyak cengkeh yang terkait dengan penghambatan kanker servik masih belum jelas. Penelitian ini, untuk mengkaji efek minyak cengkeh dari Syzygium aromaticum dalam efek proapoptosis sel kanker servik HeLa terkait dengan kadar protein p53. Tingkat apoptosis diamati dengan pewarnaan dengan Annexin-V dan PI dan dilakukan dengan metode flow-cytometry. Dilakukan pengecatan immunohistokima untuk melihat ekspresi caspase-3 aktif untuk mengonfirmasi sel yang apoptosis, sedangkan kadar protein p53 dievaluasi dari lisat sel menggunakan ELISA protein p53. Hasil studi menunjukkan bahwa minyak cengkeh memiliki efek pro-apoptosis, berkaitan dengan kadar protein p53, pada sel kanker serviks secara in vitro.
\end{abstract}

Kata Kunci: Apoptosis, minyak cengkeh, sel HeLa, Syzigium aromaticum

\section{ABSTRACT}

Cervical cancer is the most common cancer in women after breast cancer. This cancer is related to persistent infection with one of the carcinogenic human papillomavirus (HPV). This virus expresses the viral oncogenic protein E6 and E7 that are related to the carcinogenesis process. One of the mechanisms is binding E6 protein to p53 protein and inducing its degradation, resulting in anti-apoptotic effect and continuous cell proliferation. Clove oil containing eugenol has been reported to have an anti-cancer effect on several cancers. However, the mechanism of clove oil associated with cervical cancer inhibition is still not well defined. In this study, we reported the apoptotic effect of clove oil from Syzygium aromaticum in HeLa cells and p53 protein level. The apoptotic level was analyzed using flow-cytometry by staining cells with Annexin-V and PI. Immunohistochemistry of active caspase-3 to confirmed the apoptotic cells was also performed. While, the level of 553 protein was determined using the ELISA method for cell lysate. This in-vitro study showed that clove oil treatment has a pro-apoptotic effect and associated with 553 protein level in HeLa cell line.

Keywords: Apoptototic, clove oil, HeLa cells, Syzigium aromaticum

Korespondensi: Happy Kurnia P. Departemen Biokimia dan Biomolekuler Fakultas Kedokteran Universitan Brawijaya Malang, Jl. Veteran Malang65145 Tel.085259108878Email: happykp@ub.ac.id

DOI: http://dx.doi.org/10.21776/ub.jkb.2019.030.03.4 


\section{PENDAHULUAN}

Kanker serviks adalah kanker primer dari serviks yang berawal dari metaplasia epitel di zona transformasi yaitu pertemuan mukosa vagina dengan kanalis servikalis, kanker ini merupakan jenis kanker kedua terbanyak yang diderita oleh wanita di dunia dan biasanya menyerang wanita di usia 35-55 tahun (1). Pada tahun 2009 terdapat 500.000 kasus baru kanker serviks dan lebih dari 250.000 kematian yang terjadi di dunia (2). Tingginya angka kanker serviks juga tercatat di Indonesia, pada tahun 2013, penyakit kanker serviks merupakan penyakit kanker dengan tingkat prevalensi tertinggi yaitu $0,8 \%$ dengan jumlah penderita mencapai 98.692 orang (3).

Salah satu faktor etiologi kanker servik adalah infeksi virus yaitu Human Papillomavirus (HPV) $(4,5)$. Terdapat hampir 100 subtipe HPV berdasarkan variasi genetik dan potensi onkogeniknya, namun terdapat 2 tipe yaitu HPV tipe 16 dan 18 yang merupakan tipe prominen dan banyak menyebabkan kelainan genetik dan oncogenesis pada sel servik (5-7). Virus HPV mempunyai 2 protein onkogen yaitu E6 dan E7 yang berperan dalam ketidakseimbangan apoptosis dan siklus sel. Protein E6 berperan dalam inaktivasi protein p53 tumor suppressor dengan cara menginduksi degradasi protein ini. Adanya penurunan kadar p53 protein akan memberikan efek pada proteinprotein lain yang dapat mempengaruhi proses proliferasi dan apoptosis sel. Protein E7 berperan dalam inaktivasi protein $\mathrm{Rb}$ (retinoblastoma) dan mengaktivasi siklus sel (8). Ketidakseimbangan proliferasi dan apoptosis sel inilah yang menyebabkan sel berkembang terus menerus bahkan hingga dapat mengenai organ lain (metastasis). Jika kanker servik telah mengalami metastasis maka semakin sulit pengobatan yang harus diberikan pada kanker serviks ini, sehingga dapat semakin meningkatkan angka kematian akibat kanker serviks. Untuk itu dalam pencarian obat antikanker perlu menargetkan pada tiga hal yaitu penghambatan proliferasi, penginduksian apoptosis, dan penghambatan proses metastase.

Pengobatan kanker serviks di Indonesia sampai saat ini meliputi tindakan operatif, kemoterapi, dan terapi radiasi. Pada perkembangan terapi kanker, kemoterapi merupakan terapi yang paling umum digunakan, terutama untuk kanker yang telah memasuki stadium lanjut. Tetapi, efek samping penggunaannya masih tinggi karena proses selular pada sel yang sehat juga turut terganggu. Bioavailabilitas yang buruk dari agen kemoterapi dengan berat molekul yang besar serta banyak terdapatnya resistensi obat merupakan kekurangan dari kemoterapi. Selain itu, kekurangan pada terapi saat ini adalah mahalnya biaya yang harus dikeluarkan untuk proses kemoterapi (9). Diperlukan langkah baru dalam penyediaan obat-obatan di Indonesia dengan memanfaatkan senyawa bahan alam yang tersebar sangat banyak dan telah terbukti memiliki kemampuan membunuh sel kanker.

Di Indonesia cengkeh merupakan salah saktu komoditas perkebunan yang menjadi produk unggulan, karena merupakan salah satu bahan baku dari industri pembuatan rokok kretek yang menjadi unggulan industri di Indonesia (10). Senyawa eugenol merupakan senyawa utama yang terkandung di dalam minyak cengkeh (Syzygium aromaticum) dengan kandungan dapat mencapai 70-96\%. Senyawa eugenol mengandung beberapa gugus fungsional, yaitu alil $(-\mathrm{CH} 2-\mathrm{CH}=\mathrm{CH} 2)$, fenol $(\mathrm{OH})$ dan metoksi (-OCH3). Gugus inilah yang memungkinkan eugenol disintesis menjadi senyawa lain yang bernilai lebih tinggi (11).
Beberapa penelitian sebelumnya telah memperlihatkan efek anti kanker dari minyak cengkeh dengan berbagai mekanisme (12-14). Dalam penelitian ini, kami melaporkan mekanisme efek anti kanker minyak cengkeh sebagai proapoptosis sel kanker servik HeLa terkait dengan kadar protein p53. Pemberian minyak cengkeh dengan berbagai dosis mampu meningkatkan ekspresi cleaved caspase-3 diikuti apoptosis sel dan peningkatan kadar protein p53 dalam sel.

\section{METODE}

\section{Minyak Cengkeh}

Metode isolasi yang digunakan pada penelitian ini telah dilaporkan secara lengkap pada penelitian terdahulu $(15,16)$. Minyak cengkeh didapatkan dari Materia Medica Batu, diisolasi dari bunga cengkeh (Syzigium aromaticum) menggunakan pelarut n-heksana. Minyak cengkeh ditambah $\mathrm{NaOH} 4 \%$ dan disentrifugasi $100 \mathrm{rpm}$ selama 3 jam untuk mengisolasi eugenol. Eugenol yang terlarut pada larutan $\mathrm{NaOH}$ dipisahkan dan dicuci menggunakan $\mathrm{n}$ heksana kemudian ditambahkan dengan $\mathrm{HCl} 3 \%$ dan didiamkan selama 24 jam. Lapisan eugenol yang terbentuk dipisahkan, dicuci menggunakan akuades, ditambahkan $\mathrm{Na}_{2} \mathrm{SO}_{4}$ anhidrat dan didekantasi. Hasil isolasi yang diperkirakan mengandung eugenol dimurnikan dengan destilasi bervakum

\section{Inkubasi Sel dengan Minyak Cengkeh}

Kultur sel HeLa kanker serviks yang telah konfluen dibagi menjadi 4 kelompok pada 24-well plate dengan jumlah sel tiap well adalah $1 \times 10^{6} \mathrm{sel} / \mathrm{ml}$. Setiap kelompok diinkubasi dengan minyak cengkeh yang berbeda yaitu $0,50,100$, dan $200 \mu \mathrm{M}$ (dihitung berdasarkan ekivalen dosis) selama 24 jam. Pengecualian pada uji viabilitas sel, inkubasi dilakukan selama pengujian yaitu 72 jam.

\section{Kultur Sel}

Sel yang digunakan pada penelitian ini adalah sel HeLa kanker serviks yang didapat dari Laboratorium Biomedik Fakultas Kedokteran Universitas Brawijaya (Malang, Indonesia). Sel HeLa dikultur pada media RPMI-1640 dengan suplementasi $10 \%$ fetal bovin serum (FBS), dan antibiotik (100Ul/ml-Penicillin 100 $\mathrm{\mu l} / \mathrm{ml}$-streptomycin).

\section{Uji Viabilitas Sel}

Viabilitas sel dilakukan dengan pewarnaan trypan blue dan dihitung konsentrasi sel secara manual pada haemocytometer di bawah mikroskop. Sel yang viabel akan tidak terwarnai dan berpendar di bawah mikroskop cahaya, sedangkan sel yang mati akan terwarnai biru gelap. Setiap sampel dilakukan pengulangan hitung sebanyak 4 kali kemudian diambil reratanya. Setiap perlakuan dilakukan pengulangan sebanyak 3 kali.

\section{Pemeriksaan Apoptosis Sel Menggunakan Flow-Cytometry}

Sel HeLa yang akan diuji dipanen menggunakan TripsinEDTA, kemudian dicuci menggunakan PBS. Sel yang telah dicuci diwarnai menggunakan FITC Annexin $V$ Apoptosis Detection Kit with PI cat\#640914 (Biolegend, USA) sesuai dengan prosedur kit. Sel yang telah terwarnai dianalisis menggunakan mesin flowcytometry BD FACSCalibur ${ }^{\mathrm{TM}}$ (California, USA).

\section{Immunohistokima}

Sebelumnya kultur sel Hela dilakukan pada 24-well plate dengan dasar sumur diberikan cover glass berbetuk bulat ukuran $13 \mathrm{~mm}$ (Matsunami, Jepang). Primer antibodi yang 
digunakan adalah anti-rabbit Cleaved-Caspase-3 (Cell Signaling Technology, USA). Kemudian dilakukan prosedur pewarnaan immunohistokimia menggunakan Scytek immunostaining kit (Utah, USA).

\section{Pemerikasaan Kadar P53 Protein Intrasel Menggunakan} Enzymed-Linked Immunoassay (ELISA)

Sel HeLa yang telah dipanen menggunakan Tripsin-EDTA dicuci menggunakan PBS. Sel yang telah siap dilakukan isolasi protein menggunakan TRIzol reagent (Invitrogen, Carlsbad, CA, USA). Presipitasi protein dilakukan dengan penambahan isopropanol pada phenol-ethanol supernatan, kemudian disentrifugasi pada kecepatan $12000 \times$ g pada $4^{\circ} \mathrm{C}$ untuk diambil pelletnya. Pellet protein dicuci menggunkan $0,3 \mathrm{M}$ guanidine $\mathrm{HCl}$ pada $95 \%$ ethanol. Sampel protein dilarutkan pada $1 \%$ SDS. Konsentrasi protein diukur menggunakan NanoDrop ${ }^{\mathrm{TM}}$ 1000 Spectrophotometer dengan spectrum 280nm. Hasil pengukuran konsentrasi protein digunakan untuk menyamakan konsentrasi tiap sampel sebelum dilakukan pemeriksaan kadar p53 protein menggunakan p53 (human) ELISA kit ALX-850- 057-KI01 dari Bender Medsystem (Vienna, Austria) sesuai dengan prosedur yang tertera pada kit. Hasil pengukuran konsentrasi p53 dari sampel kontrol dibuat rerata dan dijadikan pembagi pada sampel perlakuan agar didapatkan rasio ekspresi protein p53 relatif terhadap kontrol (nilai p53 sampel perlakuan/nilai p53 sampel kontrol).

\section{HASIL}

Minyak Cengkeh Menginduksi Viabilitas Sel Hela

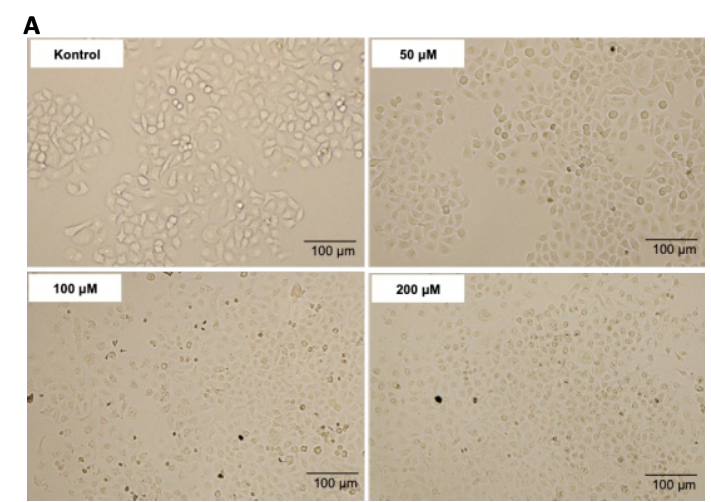

B

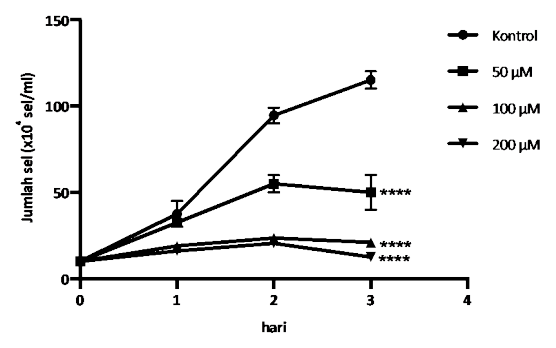

Gambar 1. Efek minyak cengkeh terhadap morfologi dan viabilitas sel HeLa

\section{Keterangan:}

A. Morfologi sel HeLa setelah paparan Minyak cengkeh dengan berbagai dosis selama 24 jam dan diamati di bawah mikroskop cahaya.

B. Jumlah sel Hela yang viabel diamati pada berbagai waktu. Data merupakan representasi means \pm SD dari 3 kali percobaan individual, $* * * * \mathrm{P}<0,0001$ (ANOVA, Tukey's multiple comparison test).
Sel HeLa diinkubasi dengan minyak cengkeh berbagai konsentrasi $(0,50,100$, dan $200 \mu \mathrm{M})$ pada medium RPMI selama 24 jam. Morfologi sel diamati menggunakan mikroskop cahaya. Setelah inkubasi selama 24 jam menggunakan minyak cengkeh, sel HeLa memperlihatkan perubahan morfologi terutama pada konsentrasi 100 dan

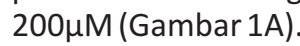

Viabilitas sel HeLa dihitung pada kamar hitung hematocytometer di bawah mikroskop cahaya pada hari ke $0,1,2$, dan 3 dengan inkubasi menggunakan minyak cengkeh. Pemberian minyak cengkeh pada sel HeLa menurunkan viabilitas sel dibandingkan dengan kontrol (Gambar 1B). Efek minyak cengkeh terhadap viabilitas sel HeLa selaras dengan konsentrasi minyak cengkeh dan waktu inkubasi. Inkubasi sel HeLa menggunakan konsentrasi $200 \mu \mathrm{M}$ minyak cengkeh selama 3 hari memperlihatkan efek yang maksimal terhadap penurunan viabilitas sel.

\section{Minyak Cengkeh Meningkatkan Apoptosis Sel HeLa}

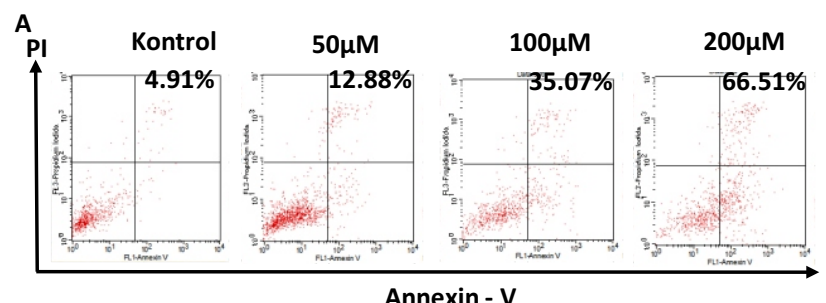

B

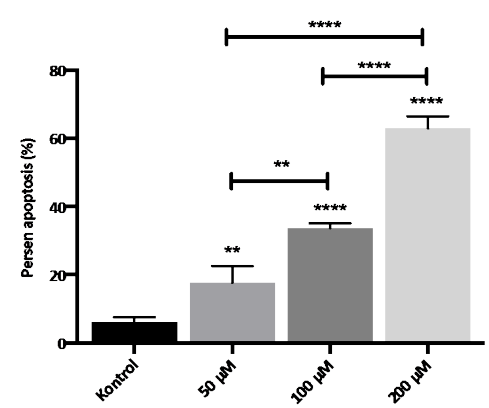

Gambar 2. Efek Minyak cengkeh terhadap apoptosis sel HeLa

Keterangan:

A. Gambar representatif dari hasil flowcytometry sel HeLa setelah pewarnaan dengan PI dan Annexin-V

B. Persen apoptosis sel HeLa yang merupakan representasi means \pm SD dari 3 kali percobaan individual, $* * \mathrm{P}<0,01 * * * * \mathrm{P}<0,0001$ (ANOVA, Tukey's multiple comparison test)

Pada penelitian ini, sel HeLa diinkubasi menggunakan minyak cengkeh $0,50,100$, dan $200 \mu \mathrm{M}$ selama 24 jam kemudian sel dipanen dan diwarnai menggunakan annexin$\mathrm{V}$ dan PI untuk dianalisis menggunakan flowcytometry. Representatif data flowcytometry dipaparkan pada Gambar $2 \mathrm{~A}$, sedangkan hasil rerata apoptosis dari tiga kali pengulangan independent dipresentasikan pada grafik (Gambar 2B). Rata-rata persen apoptosis meningkat sesuai dengan peningkatan terapi minyak cengkeh. Pada dosis $50 \mu \mathrm{M}$, rerata persen apoptosis sel HeLa adalah $17,71 \%$, sedangkan pada dosis $100 \mu \mathrm{M}$ adalah $33,79 \%$, dan rerata persen apoptosis maksimal ada pada dosis $200 \mu \mathrm{M}$ yaitu sebesar $62,99 \%$. Hasil ini mengindikasikan jumlah rerata apoptosis sel HeLa selaras dengan peningkatan dosis minyak cengkeh yang dibuktikan dengan uji korelasi Pearson dengan nilai koefisien korelasi $r=0,997$. 
Induksi Apoptosis oleh Minyak Cengkeh Ditandai dengan Peningkatan Ekspresi Cleaved-Caspase-3

A

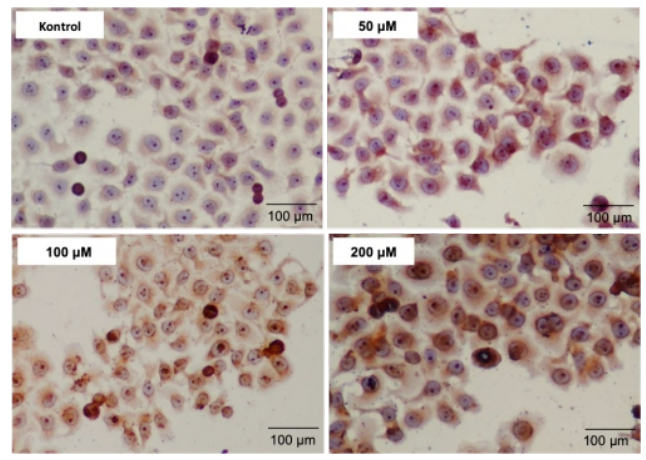

B

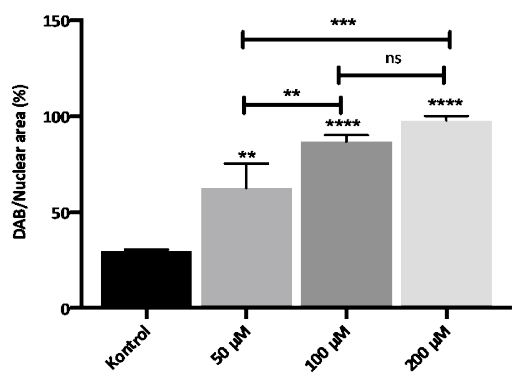

Gambar 3. Peningkatan ekspresi cleaved-caspase 3

Keterangan:

A. Gambar immmunohistokimia sel HeLa setelah pewarnaan dengan antibodi cleaved-caspase-3

B. Rasio warna DAB dan nucleus yang dihitung menggunakan aplikasi ImnnuoRatio ImageJ yang merupakan representasi rerata \pm SD dari 3 kali percobaan individual, $* * P<0,01 * * * * P<0,0001$ (ANOVA, Tukey's multiple comparison test)

Mekanisme biomolekular sel apoptosis telah banyak dipelajari dan menjadi target berbagai macam obat anti kanker. Pengaktifan cascade caspase melalui pelepasan sitokrom c dari mitokondria ke sitoplasma, merupakan salah satu mekanisme terjadinya apoptosis. Salah satu caspase yang terlibat dan merupakan caspase eksekutor adalah caspase-3. Caspase-3 dalam bentuk aktif dapat dideteksi menggunakan antibodi cleaved-caspase-3. Pemeriksaan immunohistokimia terhadap bentuk aktif caspase-3 telah direkomendasikan untuk deteksi apoptosis. Untuk itu pada penelitian ini kami mendeteksi level cleaved-caspase-3 pada sel HeLa yang telah diinkubasi menggunakan berbagai dosis minyak cengkeh

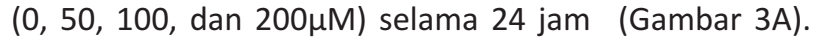
Rasio warna DAB dan inti sel dihitung menggunakan aplikasi ImmunoRatio ImageJ dan dipresentasikan dalam bentuk grafik. Dari pemeriksaan ini didapatkan hasil yang selaras dengan metode flowsitometri, yaitu peningkatan jumlah sel yang mengalami apoptosis seiring peningkatan dosis minyak cengkeh dengan nilai koefisien korelasi $r=0,9647$.

Minyak Cengkeh Meningkatkan Kadar Protein P53 Sel HeLa

Beberapa studi menyebutkan salah satu mekanisme onkogenesis pada sel kanker servik adalah penurunan kadar protein p53 akibat induksi onkoprotein E6. Onkoprotein E6 menempel pada protein p53 dan meningkatkan degradasi protein p53 melalui degradasi proteosom. Pada penelitian ini kami mengevaluasi kadar protein p53 pada lisat sel HeLa yang telah diberi beberapa dosis, minyak cengkeh. Kadar p53 protein kami evaluasi menggunakan metode ELISA, sebelumnya kami menormalisasi sampel dengan konsentrasi total protein dari lisat yang diukur menggunakan Nanodrop. Hasil ELISA p53 tiap sampel kami bagi dengan kadar kontrol sehingga didapatkan rasio peningkatan kadar p53 grup perlakuan terhadap kontrol. Terdapat peningkatan hingga 1,5 kali dari kontrol pada pemberian dosis $100 \mu \mathrm{M}$ dan $200 \mu \mathrm{M}$, namun tidak pada dosis $50 \mu \mathrm{M}$. Peningkatan kadar p53 protein ini tidak sejalan dengan peningkatan dosis dari minyak cengkeh.

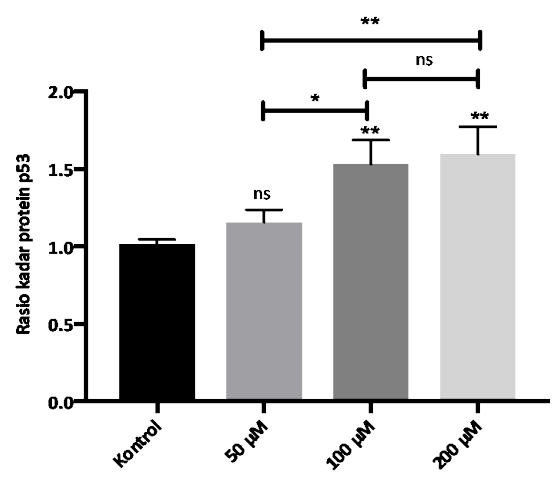

Gambar 4. Peningkatan kadar protein p53

Keterangan: Rasio kadar protein p53 dalam lisat sel HeLa yang merupakan representasi means \pm SD dari 3 kali percobaan individual, ${ }^{*} p<0,05{ }^{*} p<0,01$ (ANOVA, Tukey's multiple comparison test)

\section{DISKUSI}

Pada penelitian ini digunakan minyak cengkeh yang berasal dari minyak cengkeh (Syzygium aromaticum) yang mengandung senyawa aktif eugenol. Eugenol merupakan senyawa aktif yang terkandung pada beberapa minyak esensial seperti minyak cengkeh, kayu manis, basil, dan pala. Ekstraksi eugenol dari Syzygium aromaticum telah dibahas pada penelitian sebelumnya yang membandingkan beberapa variabel yaitu fase pendiaman setelah pengocokan dengan natrium hidroksida, dan perbandingan fase air, sehingga didapatkan eugenol dengan kualitas dan kemurnian lebih baik (15). Evaluasi secara fisik dan kimiawi hasil ekstraksi minyak cengkeh telah dibahas pada penelitian kami sebelumnya (16). Eugenol diketahui mempunyai beberapa potensi efek farmakologis seperti anastesi, antioksidant, antimikroba, antihelmin, antiinflamasi, dan antikarsinogenik $(17,18)$.

Hasil penelitian ini menunjukkan efek antikarsinogenik minyak cengkeh, khususnya pada sel kanker servik yaitu HeLa sel. Salah satu efek antikarsinogenik yang dibuktikan pada penelitian ini adalah efek proapoptosis. Pemberian minyak cengkeh dengan berbagai dosis mampu meningkatkan persentase jumlah sel yang mengalami apoptosis. Peningkatan apoptosis sel seiring dengan peningkatan dosis minyak cengkeh yang diberikan. Pemberian dosis $200 \mu \mathrm{M}$ merupakan dosis yang efektif dalam menginduksi apoptosis karena lebih dari $60 \%$ sel kanker HeLa mengalami apoptosis. Penelitian ini sejalan 
dengan penelitian sebelumnya yang memperlihatkan efek antikanker dari eugenol terhadap kanker payudara, kanker paru, melanoma, dan kanker kolon (12-14,19).

Salah satu protein efektor pada proses apoptosis adalah caspase. Aktivasi dari protein ini merupakan pertanda adanya apoptosis. Sampai saat ini terdapat 14 jenis caspase yang telah teridentifikasi, dan terbagi menjadi 3 grup yaitu caspase inflamasi, caspase inisiator apoptosis, dan caspase efektor apoptosis. Caspase-3 merupakan caspase efektor apoptosis, yang merupakan caspase yang berperan sebagai eksekutor kematian sel (20). Pada penelitian ini kami juga mengevaluasi ekspresi caspase3-aktif yaitu cleaved-caspase-3 menggunakan metode immunohistokimia. Peningkatan ekspresi caspase-3aktif sejalan dengan peningkatan dosis dari minyak cengkeh yang dibuktikan dengan nilai korelasi $r=0,9647$ melalui uji korelasi Pearson. Peningkatan ekspresi caspase-3-aktif ini menandakan pengaktifan jalur kematian sel, karena caspase-3 merupakan efektor predominan yang bertugas untuk memecah komponen sinyal yang mengakibatkan perubahan morfologi terkait apoptosis sel.

Salah satu penyebab utama dari kanker servik adalah infeksi dari human papillomavirus (HPV). Virus ini memiliki onkoprotein utama yaitu E6 dan E7 $(8,21)$. Protein E6 merupakan onkoprotein utama yang menyebabkan terjadinya onkogenesis dengan berikatan pada protein p53 pada sel yang diinfeksinya (6). Protein p53 merupakan protein tumor suppresor yang dikendalikan oleh HDM2 protein pada kondisi basal. Kedua protein ini merespon adanya sinyal onkogenik, jika terjadi stress selular maka HDM2 akan melepaskan ikatannya terhadap p53 agar protein p53 teraktivasi. aktivasi protein p53 ini akan mengendalikan siklus sel, reparasi DNA, dan menginduksi

\section{DAFTAR PUSTAKA}

1. Sulistiowati E dan Sirait AM. Pengetahuan tentang Faktor Risiko, Perilaku dan Deteksi Dini Kanker Serviks dengan Inspeksi Visual Asam Asetat (IVA) pada Wanita di Kecamatan Bogor Tengah, Kota Bogor. Buletin Penelitian Kesehatan. 2014; 42(3): 193-202.

2. Torre LA, Islami F, Siegel RL, Ward EM, and Jemal A. Global Cancer in Women: Burden and Trends. Cancer Epidemiology, Biomarkers \& Prevention. 2017; 26(4): 444-457.

3. Rasjidi I. Epidemiologi Kanker Serviks. Indonesian Journal of Cancer. 2009; 3(3): 103-108.

4. Akram Husain RS and Ramakrishnan V. A Review of Risk Factors in the Development of Cervical Malignancy. Cancer Science and Research Open Access. 2016; 3(1): 1-3.

5. Williams VM, Filippova $M$, Soto $U$, and DuerksenHughes PJ. HPV-DNA Integration and Carcinogenesis: Putative Roles for Inflammation and Oxidative Stress. Future Virology. 2011; 6(1): 45-57.

6. Hu D, Zhou J, Wang F, Shi H, Li Y, and Li B. HPV-16 E6/E7 Promotes Cell Migration and Invasion in Cervical Cancer Via Regulating Cadherin Switch in Vitro and In Vivo. Archives of Gynecology and Obstetrics. 2015; 292(6): 1345-1354. apoptosis sel sehingga tidak terjadi proses onkogenesis (22). Namun pada infeksi HPV, onkoprotein E6 akan berikatan dengan protein p53 sehingga menginduksi pelekatan protein E6AP yang merupakan E3 ubiquitin ligase enzim yang akan menginduksi terjadinya degradasi protein melalui degradasi proteasome. Degradasi p53 ini akan menyebabkan hambatan apoptosis, dan peningkatan siklus sel. Onkoprotein E6 juga akan menginduksi protein PDZ dan meningkatkan ekspresi hTERT yang mengakibatkan penghambatan apoptosis. Sedangkan onkoprotein E7 bertanggung jawab terhadap hiperfosforilasi $\mathrm{pRb}$ yang mengaktifkan faktor transkripsi E2F. Aktivasi E2F akan mengakibatkan progresifitas siklus sel. Seluruh mekanisme tersebut berkonstribusi terhadap terjadinya keganasan pada sel servik (23).

Pada penelitian ini diamati kadar protein p53 pada sel HeLa yang telah dipapar dengan minyak cengkeh. Pemberian minyak cengkeh mampu meningkatkan kadar protein p53 dalam sel. Peningkatan kadar p53 inilah yang memungkinkan induksi apoptosis pada sel HeLa. Hasil ini mengindikasikan mekanisme baru minyak cengkeh sebagai anti kanker melalui jalur lain selain sebagai antioksidan. Mekanisme bagaimana minyak cengkeh mampu meningkatkan kadar p53 protein belum diketahui secara jelas. Apakah minyak cengkeh mampu menghambat degradasi p53 ataupun meningkatkan pada level transkripsi. Pembahasan bagaimana minyak cengkeh dalam meningkatkan kadar p53 protein membutuhkan penelitian yang lebih dalam, namun hasil awal penelitian ini mampu memberikan peluang bagi penelitian lain untuk mengeksplorasi mekanisme terkait hal ini. Penelitian ini membuktikan bahwa minyak cengkeh (Syzygium aromaticum mempunyai efek proapotosis terhadap sel kanker HeLa dengan meningkatkan kadar protein p53 secara in vitro.

7. Chiantore MV, Mangino $\mathrm{G}$, Iuliano $\mathrm{M}$, et al. Human Papillomavirus E6 and E7 Oncoproteins Affect the Expression of Cancer-Related Micrornas: Additional Evidence in HPV-Induced Tumorigenesis. Journal of Cancer Research and Clinical Oncology. 2016; 142(8): 1751-1763.

8. Graham SV. The Human Papillomavirus Replication Cycle, and Its Links to Cancer Progression: A Comprehensive Review. Clinical Science. 2017; 131(17): 2201-2221.

9. Minh HV, My NTT, and Jit M. Cervical Cancer Treatment Costs and Cost-Effectiveness Analysis of Human Papillomavirus Vaccination in Vietnam: $A$ PRIME Modeling Study. BMC Health Services Research. 2017; 17(1): 1-7.

10. Nurhayati E, Hartoyo S, dan Mulatsih S. Analisis Pengembangan Ekspor Cengkeh Indonesia. Jurnal Ekonomi dan Kebijakan Pembangunan. 2018; 7(1): 21-42.

11. Towaha J. Manfaat Eugenol Cengkeh dalam Berbagai Industri di Indonesia. Perspektif. 2012; 11(2): 79-90.

12. Jaganathan SK and Supriyanto E. Antiproliferative and Molecular Mechanism of Eugenol-Induced Apoptosis in Cancer Cells. Molecules. 2012; 17(6): 6290-6304

13. Fangjun $L$ and Zhijia Y. Tumor Suppressive Roles of Eugenol in Human Lung Cancer Cells. Thoracic Cancer. 
2018; 9(1): 25-29.

14. Júnior PLDS, Câmara DAD, Costa AS, et al. Apoptotic Effect of Eugenol Envolves G2/M Phase Abrogation Accompanied by Mitochondrial Damage and Clastogenic Effect on Cancer Cell In Vitro. Phytomedicine. 2016; 23(7): 725-735.

15. Senapati R, Senapati NN, and Dwibedi B. Molecular Mechanisms of HPV Mediated Neoplastic Progression. Infectious Agents and Cancer. 2016; 11(1): 59.

16. Rahman MF, Haykal MN, Siagian NA, Sriepindonnta PM, and Tampubolon NA. Synthesis and Proapoptotic Activity on Cervical Cancer Cell of Ester Eugenol 1-(3-Methoxy-4-hydroxy)phenyl-2propylmethanoate. Conference Series: Materials Science and Engineering. 2018; 299(1): 1-7.

17. Raja MRC, Srinivasan V, Selvaraj S, and Mahapatra SK. Versatile and Synergistic Potential of Eugenol: A Review. Pharmaceutica Analytica Acta. 2015; 6(5): 367-373.

18. Bezerra DP, Militão GCG, de Morais MC, and de Sousa DP. The Dual Antioxidant/Prooxidant Effect of
Eugenol and Its Action in Cancer Development and Treatment. Nutrients. 2017; 9(12): 1-15.

19. Al-Sharif I, Remmal A, and Aboussekhra A. Eugenol Triggers Apoptosis in Breast Cancer Cells Through E2F1/Survivin Down-Regulation. BioMed Central Cancer. 2013; 13: 601-610.

20. Arya R and White K. Cell Death in Development: Signaling Pathways and Core Mechanisms. Seminars in Cell \& Developmental Biology. 2015; 39: 12-19.

21. Martín AG. Molecular Biology of Cervical Cancer. Clinical and Translational Oncology. 2007; 9(6): 347354.

22. Joerger AC and Fersht AR. The $p 53$ Pathway: Origins, Inactivation in Cancer, and Emerging Therapeutic Approaches. Annual Review of Biochemistry. 2016; 85(1): 375-404.

23. Senba M and Mori N. Mechanisms of Virus Immune Evasion Lead to Development from Chronic Inflammation to Cancer Formation Associated with Human Papillomavirus Infection. Oncology Review. 2012; 6(2): 135-144. 